\title{
A Study on the Effect of High-Speed Railway on Economic Growth of Beijing-Tianjin-Hebei Urban Agglomeration
}

\author{
Chenyang Wang ${ }^{1, *}$ \\ ${ }^{1}$ School of Economics and Management, Beijing Jiaotong University, 100044 Beijing, China
}

\begin{abstract}
In order to measure the value of high-speed railway in the development of Beijing-Tianjin-Hebei urban agglomeration and provide empirical support for the rationality of "eight horizontal and eight vertical" planning, based on the impact mechanism of high-speed railway on economic growth, this paper uses the data of 13 prefecture level cities in Beijing-Tianjin-Hebei urban agglomeration from 2009 to 2017 to quantitatively study the economy of Beijing-Tianjin-Hebei urban agglomeration triggered by high-speed railway Growth effect. The empirical results show that the overall effect of high-speed railway on economic growth of BeijingTianjin-Hebei urban agglomeration is 0.545 in the past two years, which is a large positive effect. The highspeed railway can not only directly stimulate the economic growth of Beijing-Tianjin-Hebei urban agglomeration by expanding the scale of capital investment, but also indirectly promote the economic growth of Beijing Tianjin Hebei urban agglomeration by promoting the development of system, technology, labor force and industrial structure, which proves the value of high-speed railway. Finally, according to the empirical results, it provides reasonable feasible suggestions to the relevant government departments.
\end{abstract}

\section{Introduction}

High-speed railway has a high standard of design speed, which can be used for trains running at a speed of not less than $250 \mathrm{~km} / \mathrm{h}$ on the track. In 2004, China proposed the planning task of constructing "four horizontal and four vertical" high-speed rail network, which is now largely completed. Now, China is steadily developing in the process of promoting the "eight horizontal and eight vertical" new planning proposed in 2016. Under the background of the rapid development of high-speed railway construction, to explore the role and status of high-speed railway in promoting China's economic growth will be an important basis for judging the social value of high-speed railway. As China's political and cultural center, Beijing-Tianjin-Hebei urban agglomeration is also one of the earliest regions to open high-speed railway in China. Therefore, Beijing-TianjinHebei urban agglomeration is selected as the research object of high-speed railway on urban economic growth.

In recent years, the rapid development of high-speed railway construction in the world, especially in Europe and Asia, has attracted the attention and discussion of Chinese and foreign scholars on the impact of high-speed railway on urban economic growth. However, there are some differences among the research results of various scholars.

The mainstream view accepted by many scholars is that high-speed railway can play a positive role in promoting urban economic growth, and high-speed railway will affect urban economic growth in two ways: direct and indirect. By contrast, some scholars believe that the high-speed railway has not played a significant role in promoting the economic growth of cities, especially the underdeveloped cities.

Based on the analysis of domestic and foreign viewpoints, the conclusion is that high-speed railway can affect urban economic growth, which is a fact recognized by scholars at home and abroad. The mechanism of its influence on urban economic growth is complex, and high-speed railway will indirectly affect economic growth through multiple factors. Few scholars use structural equation model to study the impact of high-speed railway on urban economic growth, and structural equation model has good application effect in exploring the relationship between multiple variables. Therefore, this paper uses structural equation model to quantitatively study the impact of high-speed railway on the economic growth of Beijing-Tianjin-Hebei urban agglomeration, and provides empirical support for the rationality and significance of "eight horizontal and eight vertical" planning, which has certain innovative value.

\section{Materials and Methods}

\subsection{Structural equation model}

In reality, there are some statistical variables in the field of social science which are difficult or unable to obtain data through direct measurement. These variables are called latent variables, and they are usually evaluated indirectly by some observed variables which are easy to

\footnotetext{
Corresponding author: 19120532@bjtu.edu.cn
} 
measure numerically. Structural equation model (SEM) can provide a solution to the problem of studying the relationship between multiple latent variables and corresponding observed variables based on maximum likelihood estimation. Therefore, this paper chooses structural equation model as an empirical analysis tool.

Capital investment, industrial structure, technological level, institutional factors and labor force level are the core elements that can not be ignored in the process of economic growth in the new economic geography theory and urban economics theory. Further combining with the theory of transport economics, high-speed rail, as a new type of transportation infrastructure, will have a certain impact on these elements. Therefore, it is necessary to take these factors into consideration as potential variables when constructing the structural equation model of the mechanism and path of high-speed railway on the economic growth of Beijing-Tianjin-Hebei urban agglomeration, and select reasonable observation variables on this basis.

\subsection{Variable selection and data source}

Based on the data of 12306 website, the schematic diagram of China's high-speed railway network published by the high-speed railway network, and the statistical yearbook of China City Statistical Yearbook and China Statistical Yearbook For Regional Economy published by the National Bureau of Statistics over the years, this paper obtains the data of 13 prefecture level cities in the BeijingTianjin-Hebei urban agglomeration from 2009 to 2017 for research. In addition to the number of high-speed railway stations, the other 12 variables are logarithmically processed. In order to balance the impact of inflation, the monetary related data after 2010 (including 2010) are deflated. Table 1 shows the selection of observation variables and the descriptive statistical results of all observed variables:

\begin{tabular}{|c|c|c|c|c|c|c|}
\hline $\begin{array}{c}\text { Latent } \\
\text { variable }\end{array}$ & $\begin{array}{l}\text { Observed } \\
\text { variable }\end{array}$ & Meaning & $\begin{array}{l}\text { Number of } \\
\text { samples }\end{array}$ & Average & Maximum & Minimum \\
\hline \multirow{2}{*}{$\begin{array}{l}\text { High-speed } \\
\text { railway }\end{array}$} & $\mathrm{X}_{1}$ & $\begin{array}{c}\text { Number of high speed railway lines passing through } \\
\text { urban high speed railway stations }\end{array}$ & 117 & 1.13 & 5.00 & 0.00 \\
\hline & $\mathrm{X}_{2}$ & Number of urban high speed railway stations & 117 & 2.01 & 13.00 & 0.00 \\
\hline \multirow{2}{*}{$\begin{array}{l}\text { Capital } \\
\text { investment }\end{array}$} & $\mathrm{X}_{3}$ & $\begin{array}{l}\text { Logarithm of total investment in fixed assets of the } \\
\text { whole society }\end{array}$ & 117 & 16.86 & 18.69 & 15.10 \\
\hline & $\mathrm{X}_{4}$ & $\begin{array}{c}\text { Logarithm of completed investment in real estate } \\
\text { development }\end{array}$ & 117 & 15.03 & 17.56 & 12.97 \\
\hline \multirow{2}{*}{$\begin{array}{l}\text { Industrial } \\
\text { structure }\end{array}$} & $\mathrm{X}_{5}$ & $\begin{array}{l}\text { Logarithm of the proportion of secondary industry } \\
\text { in GDP }\end{array}$ & 117 & 3.81 & 4.13 & 2.94 \\
\hline & $\mathrm{X}_{6}$ & $\begin{array}{l}\text { Logarithm of the proportion of the tertiary industry } \\
\text { in GDP }\end{array}$ & 117 & 3.72 & 4.39 & 3.35 \\
\hline \multirow{2}{*}{$\begin{array}{l}\text { Technical } \\
\text { level }\end{array}$} & $\mathrm{X}_{7}$ & Logarithm of science and technology expenditure & 117 & 10.69 & 15.10 & 8.61 \\
\hline & $\mathrm{X}_{8}$ & Logarithm of education expenditure & 117 & 13.63 & 16.08 & 12.09 \\
\hline \multirow{2}{*}{$\begin{array}{l}\text { Institutional } \\
\text { factors }\end{array}$} & $\mathrm{X}_{9}$ & Logarithm of general public budget expenditure & 117 & 15.29 & 18.04 & 13.71 \\
\hline & $\mathrm{X}_{10}$ & Logarithm of the actual utilization of foreign capital & 117 & 11.12 & 14.94 & 7.38 \\
\hline \multirow{2}{*}{$\begin{array}{l}\text { Labor force } \\
\text { level }\end{array}$} & $\mathrm{X}_{11}$ & Logarithm of the number of employees in the unit & 117 & 4.22 & 6.70 & 3.06 \\
\hline & $\mathrm{X}_{12}$ & $\begin{array}{l}\text { Logarithm of the number of registered residence } \\
\text { population at the end of the year }\end{array}$ & 117 & 6.52 & 7.22 & 5.66 \\
\hline \multirow{2}{*}{$\begin{array}{l}\text { Economic } \\
\text { growth }\end{array}$} & $\mathrm{X}_{13}$ & Logarithm of urban GDP & 117 & 17.15 & 19.45 & 15.69 \\
\hline & $\mathrm{X}_{14}$ & Logarithm of urban per capita GDP & 117 & 10.64 & 11.91 & 9.63 \\
\hline
\end{tabular}

\section{Results \& Discussion}

\subsection{The results of model}

According to the principle of structural equation model, this paper uses Amos21.0 software to take the sample data of 13 prefecture level cities in the Beijing-Tianjin-Hebei urban agglomeration from 2009 to 2017 as the observation variables representing each latent variable to construct the structural equation model, and obtains the relationship model of structural variables and path coefficient of economic growth of Beijing-Tianjin-Hebei urban agglomeration by high-speed railway as shown in Figure 1: 


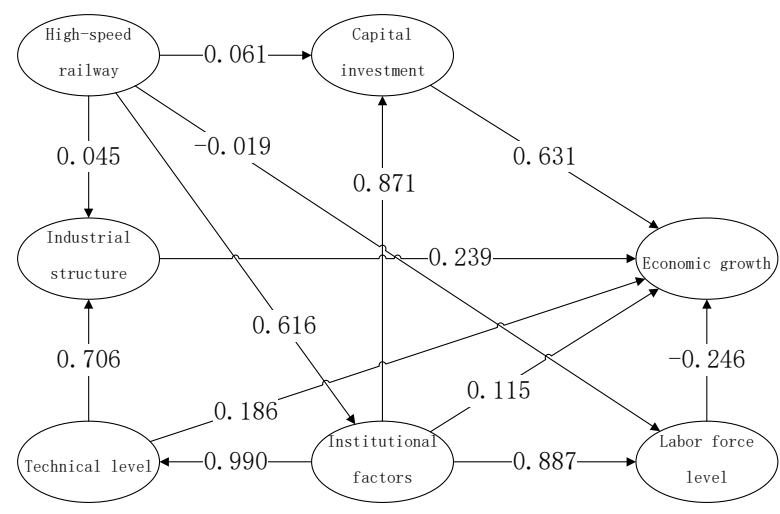

Fig 1. Structural equation model of the influence of high speed railway on the economic growth of Beijing-

Tianjin-Hebei urban agglomeration.

After observing the overall model test indexes given in Table 2, it is found that the CMIN/DF value in the absolute fitness statistics of the model is not more than 20 , the GFI value is close to 0.9 , and the RMSEA value is less than 0.2 , which meets the standard of passing the absolute fitness test. The NFI, IFI and CFI values in the incremental fitness statistics are all more than 0.9, which meets the requirements of passing the incremental fitness test. Therefore, it is considered that the model and its results are reasonable and reliable. And all the estimated results of the standardized influence coefficients among the latent variables have passed the significance test.

Table2. Inspection index of overall model.

\begin{tabular}{|c|c|c|c|c|c|c|}
\hline Index & $\begin{array}{c}\text { CMIN } \\
\text { /DF }\end{array}$ & GFI & $\begin{array}{c}\text { RMSE } \\
\text { A }\end{array}$ & NFI & IFI & CFI \\
\hline Value & 12.066 & 0.865 & 0.109 & 0.901 & 0.914 & 0.913 \\
\hline $\begin{array}{c}\text { Stand- } \\
\text { ard }\end{array}$ & $<20$ & $>0.8$ & $<0.2$ & $>0.9$ & $>0.9$ & $>0.9$ \\
\hline
\end{tabular}

\subsection{The discussion of results}

The coefficient between latent variables means that if one variable changes by one unit, other variables will change accordingly. Table 3 lists the influence coefficient values among the latent variables:

Table3. Direct effect, indirect effect and total effect among latent variables (standardized results).

\begin{tabular}{|c|c|c|c|c|c|c|c|}
\hline $\begin{array}{c}\text { Influence } \\
\text { variable }\end{array}$ & $\begin{array}{c}\text { Affected } \\
\text { variable }\end{array}$ & $\begin{array}{c}\text { Capital } \\
\text { investment }\end{array}$ & $\begin{array}{c}\text { Industrial } \\
\text { structure }\end{array}$ & $\begin{array}{c}\text { Technical } \\
\text { level }\end{array}$ & $\begin{array}{c}\text { Institutiona } \\
1 \text { factors }\end{array}$ & $\begin{array}{c}\text { Labor force } \\
\text { level }\end{array}$ & $\begin{array}{c}\text { Economic } \\
\text { growth }\end{array}$ \\
\hline \multirow{3}{*}{$\begin{array}{l}\text { High-speed } \\
\text { railway }\end{array}$} & Direct effect & .061 & .045 & - & .616 & -.019 & - \\
\hline & Indirect effect & .537 & .430 & .610 & - & .546 & .545 \\
\hline & Total effect & .598 & .475 & .610 & .616 & .527 & .545 \\
\hline \multirow{3}{*}{$\begin{array}{l}\text { Industrial } \\
\text { structure }\end{array}$} & Direct effect & - & - & - & - & - & .631 \\
\hline & Indirect effect & - & - & - & - & - & - \\
\hline & Total effect & - & - & - & - & - & .631 \\
\hline \multirow{3}{*}{$\begin{array}{l}\text { Industrial } \\
\text { structure }\end{array}$} & Direct effect & - & - & - & - & - & .239 \\
\hline & Indirect effect & - & - & - & - & - & - \\
\hline & Total effect & - & - & - & - & - & .239 \\
\hline \multirow{3}{*}{$\begin{array}{c}\text { Technical } \\
\text { level }\end{array}$} & Direct effect & - & .706 & - & - & - & .186 \\
\hline & Indirect effect & - & - & - & - & - & .169 \\
\hline & Total effect & - & .706 & - & - & - & .355 \\
\hline \multirow{3}{*}{$\begin{array}{l}\text { Institutional } \\
\text { factors }\end{array}$} & Direct effect & .871 & - & .990 & - & .887 & .115 \\
\hline & Indirect effect & - & .699 & - & - & - & .683 \\
\hline & Total effect & .871 & .699 & .990 & - & .887 & .798 \\
\hline \multirow{3}{*}{$\begin{array}{c}\text { Labor force } \\
\text { level }\end{array}$} & Direct effect & - & - & - & - & - & -.246 \\
\hline & Indirect effect & - & - & - & - & - & - \\
\hline & Total effect & - & - & - & - & - & -.246 \\
\hline
\end{tabular}

According to the empirical results of structural equation model, the effects of high-speed railway and other factors on the economy of Beijing-Tianjin-Hebei urban agglomeration include direct effect, indirect effect and total effect. According to Figure 1, the direct effect of capital investment on the economic growth of BeijingTianjin-Hebei urban agglomeration is the most obvious, and the coefficient can reach 0.631 , which means that when other conditions remain stable, an increase of 1 unit of capital investment will directly increase the economic growth by 0.631 unit. The industrial structure, institutional factors, technical level and labor force level will have a direct impact on the economic growth of Beijing-Tianjin-Hebei urban agglomeration, and the path coefficients are $0.239,0.115,0.186$ and -0.246 respectively, which means that once other conditions except labor force level are improved, the economic level of Beijing-Tianjin-Hebei urban agglomeration will also increase. As a developing country, China's population growth rate has always maintained growth from 2010 to 2017, which leads to the surplus of labor force resources compared with other economic resources, and the mismatch between other economic resources and labor force resources. On the contrary, the increase of labor force limits the urban economic growth.

According to Table 3, the overall effect of high-speed railway on the economic growth of Beijing-Tianjin-Hebei urban agglomeration is 0.545 , which is greater than the overall effect of industrial structure, technical level and labor level on the economic growth of the city, which means that for the economic level of Beijing-TianjinHebei urban agglomeration, high-speed railway is an important factor that can play a great role in promoting. Capital investment has the most obvious direct impact on the economic growth of Beijing-Tianjin-Hebei urban agglomeration, and the whole process of high-speed 
railway from construction to operation, the manufacturing and maintenance of hardware facilities such as train, track and control equipment, and the operation and maintenance of software such as database, operating system and management system all need huge expenses. This will drive the continuous demand of the market for building raw materials and high-tech, so as to improve the treatment level of employees in related industries. After the increase of income of relevant personnel, it will certainly improve the consumption level of daily necessities and leisure entertainment, promote the vigorous development of health management, entertainment and leisure industries, so as to realize a virtuous circle of "investment, production, income and consumption". The promotion of the overall national income level will effectively drive the economic growth of Beijing-Tianjin-Hebei urban agglomeration.

The continuous advancement of high-speed railway construction will directly or indirectly affect the institutional factors, technical level, labor level and industrial structure to some extent. These factors will respectively affect the economy of Beijing-Tianjin-Hebei urban agglomeration, thus making the high-speed railway realize the function of indirectly affecting economic growth.

\section{Conclusions}

In order to explore the value of high-speed railway in China's economic growth and provide empirical support for the rationality of "eight horizontal and eight vertical" planning, this paper uses the data of 13 prefecture level cities in Beijing-Tianjin-Hebei urban agglomeration from 2009 to 2017, based on the influence mechanism of highspeed railway on economic growth, and uses structural equation model to quantitatively study the economic growth effect of Beijing-Tianjin-Hebei urban agglomeration caused by high-speed railway. The empirical results show that the overall economic growth effect of Beijing-Tianjin-Hebei urban agglomeration caused by high-speed railway in the past two years is 0.545 , which is a significant positive effect. High-speed railway can not only stimulate the urban economic growth directly by stimulating capital investment, but also indirectly promote the economic growth of BeijingTianjin-Hebei urban agglomeration by promoting the improvement of system, the improvement of technology level, the improvement of labor force level and the transformation and upgrading of industrial structure. The economic growth of Beijing-Tianjin-Hebei urban agglomeration proves that the construction of high-speed railway is valuable.

According to the conclusions, this paper puts forward the following suggestions: (1) Based on the fact that the high-speed railway will significantly promote the urban economic growth through direct and indirect effects, it is necessary to continuously promote the construction of high-speed railway in the future. (2) When formulating policies on various factors such as industrial structure, it is necessary for relevant national departments to consider the effects of high-speed railway on all aspects of society, so as to formulate more comprehensive policies. (3) While promoting the construction of high-speed railway, they should also be alert to the siphon effect, and cities along the way can formulate more attractive talent policies according to the specific conditions to attract high-quality talents to settle in place.

\section{Acknowledgments}

This paper is one of the phased achievements of national key R\&D program of China (2018YFB1201401).

\section{References}

1. Nakamura. H, Ueda T. The Impacts of Shinkansin on Regional Development [J].Proceedings of WCTR , 1989, (3):95-109.

2. Vickerman R, Ulied A. Indirect and wider economic impacts of high speed rail[J]. Economic analysis of high speed rail in Europe, 2006, 1:89-118.

3. Ahlfeldt G M, Feddersen A. From periphery to core: measuring agglomeration effects using high-speed rail[J]. Journal of Economic Geography, 2017, 18(2): 355-390.

4. Preston J, Wall G. The Ex-ante and Ex-post Economic and Social Impacts of the Introduction of High-speed Trains in South East England[J]. Planning Practice \& Research, 2008, 23(3):403-422.

5. Chen $\mathrm{C}$ L, Hall P. The wider spatial-economic impacts of high-speed trains: a comparative case study of Manchester and Lille sub-regions[J]. Journal of Transport Geography, 2012, 24:89-110.

6. NIAN M. Transportation Infrastructure, Economic Growth and Spatial Equalization-Natural Experiment Based on High-speed Railway in China[J]. Finance \& Trade Economics, 2019,40(08):146-161. 